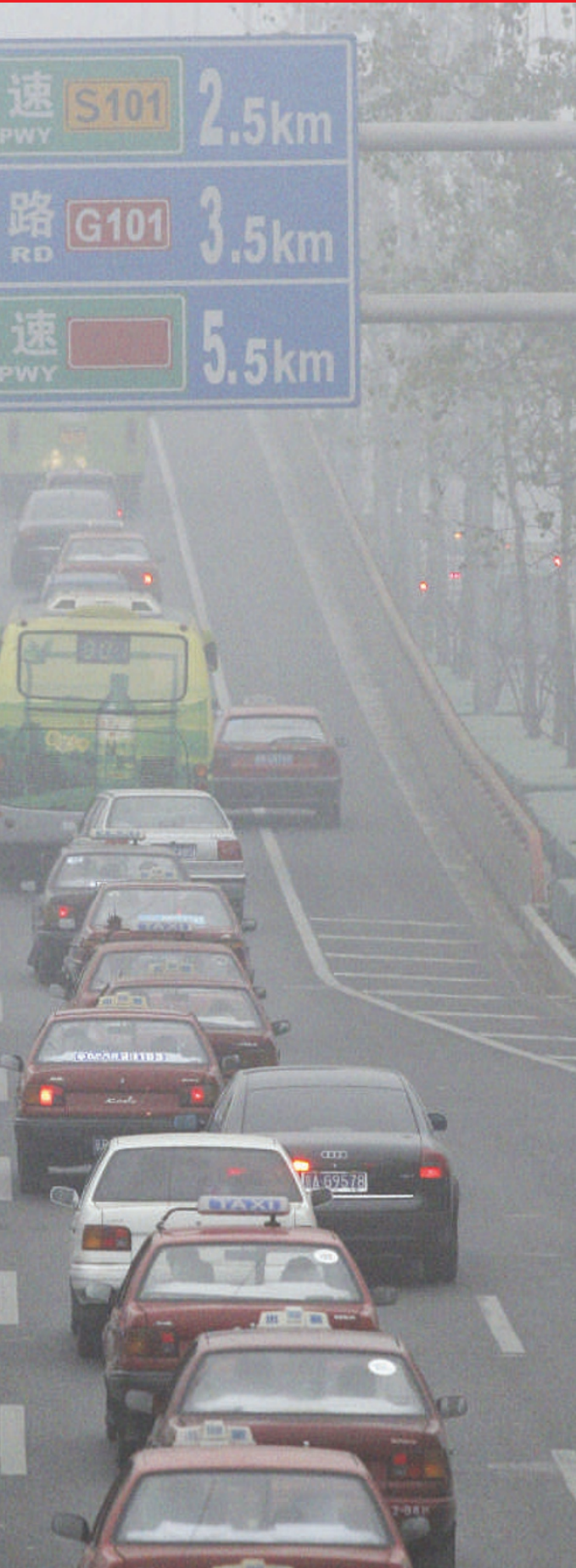

unreported, for example, or, for a single year, a figure will inexplicably drop to zero. Marland says that, as a result, any estimates of China's emissions could be off by $15-20 \%$.

$\mathrm{He}$ adds that the considerable amount of carbon dioxide produced in making cement, if included in the figures, could also tip the balance. China produces $45 \%$ of the world's cement. "China could be exceeding the United States right now," Marland says.

Further details of China's carbon dioxide emissions may have to wait until next year, when NASA plans to launch the Orbiting Carbon Observatory. The satellite is designed to provide high-resolution data on worldwide carbon dioxide emissions. David Cyranoski

See Editorial, page 949

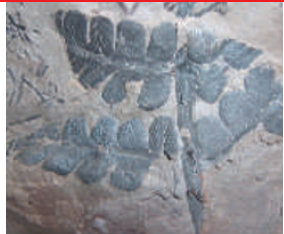

FOSSILFOREST

Extinct species found in coal mine.

www.nature.com/news

\title{
Primate work faces German veto
}

German scientists have condemned a parliamentary decision to stop primate experiments at the University of Bremen, calling it unacceptable political interference with the freedom to conduct research.

Animal-rights activists in the state of Bremen have been campaigning for years against the macaque experiments of Andreas Kreiter, a neuroscientist at the university's brain research centre. Now, in the run-up to regional elections on 13 May, the activists have finally won cross-party political support.

Bremen's parliament last month unanimously asked the state government not to reapprove Kreiter's experiments from the end of 2008, when his licence becomes due for renewal. Meanwhile, a commission of scientists and representatives of animal-protection groups is to re-evaluate the scientific value of Kreiter's research, and assess whether the experiments could be replaced by non-invasive methods. Both issues have been addressed before by granting agencies and by the local authorities and ethics committees, Kreiter says.

Neither the state parliament nor the state government can order the university to close down the centre. But Kreiter fears that political pressure will force the local authorities not to approve further experiments.

"This decision was motivated by the election campaign," says Matthias Kleiner, president of the DFG, Germany's main funding agency for university research. "It's an attempt to interfere with the constitutionally guaranteed freedom to research. We hope that the approval authorities in charge will decide solely on the basis of applicable law."

Primate researchers in Germany are used to violent protests. Kreiter's research, on cognitive processes such as attention, involves placing electrodes in monkeys' brains. $\mathrm{He}$ and his family were put under police protection in 1997 after they received threatening letters. Attacks have since ceased, but in March animal campaigners submitted to Bremen's parliament 15,000

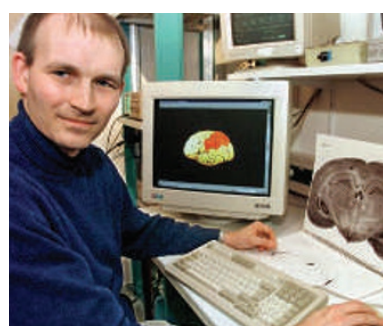

"It seems weird that the same people who have fought me to the finish will now judge my work."

- Andreas Kreiter

signatures from people who opposed the experiments.

Considering the ethical pros and cons of animal experiments is always crucial, says Alexander Thiele, a brain researcher at Newcastle University, UK. But he says that the level of political interference with Kreiter's project, which has been approved both legally and ethically, is "scandalous".

Thiele had been offered a professorship at the Humboldt University in Berlin, which he rejected when local authorities last week denied approval for his planned experiments on visual attention in macaques. He says that such blatant political intervention at a local level is less common in Britain because experiments there are approved by the Home Office.

The state science ministry in Bremen, which oversees the university, is also unhappy with the parliamentary decision. "This is very disturbing," says Holger Bienhold, a ministry official in charge of the natural sciences. "It's hardly conceivable to stop a professor from doing legally and ethically approved research."

Kreiter has won around $€ 3$ million (US\$4 million) in grant money from various sources, including the DFG, the federal science ministry, and the European Union.

Kreiter is determined to continue his research in Bremen, and has started to prepare for possible lengthy lawsuits. The commission is due to release its review of his work is due in June. "It seems weird to me that the same people who have fought me to the finish will now judge my work," he says. "They will most likely misuse every bit of information they can get."

But the experiments are cruel to animals, says Wolfgang Apel, president of the German Animal Welfare Association and organizer of the petition against Kreiter's work. The committee, he says, will suggest how, and not just whether, the experiments will be phased out.

Alternatives to some types of invasive experiments on primates do exist. For example, functional magnetic resonance imaging can effectively measure activity in large groups of brain cells. But to measure the activity of individual neurons, which is crucial to study cognitive processes such as visual attention, electrodes must be directly inserted into a monkey's brain.

Quirin Schiermeier 